\title{
CASTED MASCULINITIES IN THE PUNJABI DIASPORA IN SPAIN
}

\begin{abstract}
This paper discusses how young, unmarried Indian men of Punjabi origin from an exuntouchable caste negotiate masculinity in a first-generation migration context in Barcelona, Spain. Based on fieldwork carried out over a two-year period, the paper explores how men assert their masculinity through economics, moral leadership, caste pride, and the exaltation of Indian gender norms. It discusses how the majority of young Punjabi men in Spain are "gender blind”, and adhere ideologically to a hegemonic form of masculinity. It finds that Dalit men, in response to the devaluation of their masculinity by upper-caste and Spanish men, respond by valuing their masculinity as superior and investing in upward mobility.
\end{abstract}

Keywords: masculinities, Indian diaspora, caste, gender values. Word count: 10, 029.

\section{Introduction}

The extent to which gender values and norms are reproduced by migrant communities in their adopted country of residence is a key area of research interest across a number of disciplines, and also of particular concern to policy makers coming to grips with gender-related integration issues. Interest in potential change in gender norms has tended to focus on migrant women, and is often based on the assumption that contact with a different set of gender norms will produce a positive change in migrant attitudes and behavior. This paper sets out to interrogate that assumption by addressing, from an anthropological perspective and methodology, the 
question of masculine identity and gender change in a first-generation migration context. ${ }^{1}$ The gender attitudes and ideologies of young (18-30), unmarried Punjabi Indian men from the Ravidassia caste living in Barcelona, Spain are explored; a group that is a triple minority: an ethnic minority in Spain, a religious minority in India, and an oppressed caste group within Punjabi society.

The Ravidassias are Dalits ${ }^{2}$ from the Punjab state of India who started migrating to Spain beginning in the early 1990's. As a former untouchable caste, the Ravidassias, who are also known colloquially as "Chamar”, a term derived from their traditional occupation of leather work, continue to face strong social stigma and negative stereotyping despite the legal abolishment of untouchability in 1950. Although physical untouchability (the prohibition on sharing food or water with Dalits) in the Punjab is receding, social untouchability persists. Recent advances in Ravidassia education rates, employment and access to migration, have improved their economic position, and led to a flowering of caste consciousness and greater awareness of their civil rights. The global Ravidassia diaspora is now growing quite quickly, and has settled in new destinations for Punjabi migration such as Spain, drawn by Spain's previously booming construction industry as well as greater possibilities to obtain legal residence than in other European countries. The Ravidassias provide an interesting case study of the intersection of gender, and in particular the study of masculinities, with race, caste and ethnic minority status in a country that has historically been a source of emigrants. While the Ravidassias are 'marked' as a visible minority in Spanish society, they are also 'marked', in a variety of more subtle ways, as low caste within the Punjabi diaspora living in Spain.

A major contribution of the masculinities literature has been to highlight how gender relations are configured not only by the relations between men and women, but also by intra-male relations, and in particular, by men's relationship to local manifestations of dominant 
masculinity. A key question that has emerged has been how individual men identify with and contest these idealised masculinities. Previous research in the field of South Asian masculinities has shown that low-caste men in India in particular struggle with fulfilling the expectations of Indian dominant masculinity, known as mardangi in Hindi/Punjabi, which stresses providing for one's family and displaying wealth via consumption, due to poverty (Jackson, 1999; de Neve 2004). This study, by focusing on the relationship of young Dalit men to both Indian and Spanish dominant masculinities, builds on this literature by studying the psychological investment in dominant masculinity in a context of diasporic upward social mobility and growing caste pride. My research shows that the 'mental maps' of masculinity are multiple, yet remain hierarchically ordered, with the Indian model of dominant masculinity more emotionally powerful. As a minority group that has long struggled for basic human rights (historically, Punjabi Dalits were forbidden from owning land, subject to myriad restrictions in accessing education, and extensive social segregation), and in a contemporary context of caste assertion and inter-caste economic competition in both Spain and India, male self-esteem is also linked to the upward mobility of the broader Ravidassia community. Hence community assertion is simultaneously imbricated with individual masculinities. While a number of studies (e.g., Hoodfar 1997; Rao 1999; Ray 2000), have shown the symbolic importance of women in representing nations and communities, I argue that Ravidassia men also have a 'symbolic burden' in upholding Ravidassia identity. Whereas for Jat Sikh men pride in the turban has become a trope for the entire community (particularly in the diaspora), for the low caste Ravidassias, achieving economic power has become their symbol and passport. In pursuing wealth accumulation, Ravidassia men demonstrate their ability to live up to dominant masculine ideals and vindicate their community after centuries of both legally enshrined and social discrimination. In exploring how gender norms operate within the Punjabi diaspora in Spain, I first focus on the Ravidassia temple as a site of gender training and policing within the 
community. Until 2009, the Spanish Ravidassias followed a heterodox form of Sikhism and identified broadly with the Sikh faith. However, the killing in 2009 of one of their spiritual leaders led the community to breaking formally with Sikhism, removing the Sikh scriptures, and declaring a separate Ravidassia dharam or faith community. Despite this dramatic schism however, the temple remains the centre of Ravidassia community life. As the institution around which the majority of the community pivots, the temple is an important reference point for both masculine and feminine identity production. I then discuss how young Punjabi men view gender roles, their awareness of gender inequality, and the importance to Punjabi masculinity of three key categories of manliness: economics, physical/moral strength and heterosexuality. I will conclude by comparing how young Punjabi men perform their masculinities in Spain versus India, in order to shed light on the question of how new forms of masculinity might take shape in the diaspora.

\section{Theoretical considerations: Scholarship on Masculinities}

The field of Masculinity Studies interrogates how masculinity is socially constructed, historically/culturally specific, multiple, and hierarchically ordered. It developed in response to women's studies and its emphasis on unequal gender relations in all human societies. Both Kimmel and Connell emphasise the importance of hegemonic masculinity in defining what it means to be a man. According to Kimmel, "all masculinities are not created equal....one definition of manhood continues to remain the standard against which other forms of manhood are measured" (Kimmel 1994: 124). Connell asserts that hegemonic masculinity is “constructed in relation to various subordinated masculinities as well as in relation to women” (Connell 1987: 183). Hegemonic masculinity does not imply total cultural dominance: it does not erase alternatives, but rather subordinates them (Connell 1987: 184). Nor does hegemonic 
masculinity mean that all men conform in practice to its ideals. Connell argues that its power derives from an image of masculinity that men identify with psychologically and perceive as the standard of masculinity (Connell 1987: 185). What men support ideologically is not necessarily how they behave, but what they use as an invisible, internalised standard to guide them (even if they don't agree with the entire canon of masculinity). Hegemonic masculinity thus gains its power by acting as a reference point against which men judge not only their masculinity, but also their entire personhood. As Goffman notes, our gender identity is a deeply-rooted source of identification that profoundly influences our self-concept (Goffman 1977: 304).

In American society, what Kimmel calls “marketplace masculinity” has become the normative standard against which all other forms of masculinity are judged. Marketplace masculinity must be proved, and "requires the acquisition of tangible goods as evidence of success" (Kimmel 1994: 124). It defines itself by excluding a series of others: "women, nonwhite men, nonnativeborn men, homosexual men...” (Kimmel 1994: 124). In a similar vein, Connell, analysing the "global gender order", stresses that in every historical period, a certain hierarchical configuration of masculinities has reigned. Under colonialism, imperial powers, just as they created hierarchical classifications of race and nation, also created a 'scale of masculinities'. Thus, colonial powers distinguished between manly and effeminate groups among the nations that they had subjugated (Connell 2005: 75). In colonial India, the British defined certain Indian ethnic groups, such as the Sikhs as "martial races”, and considered others, such as the Bengalis, to be effeminate.

Thus it is clear that rather than speak of manhood as some timeless essence that men 'naturally' possess, it is important to view masculinity as a set of power relations that discipline men by compelling them to continually prove their manhood. This constant pressure to prove one's 
masculinity by devaluing women and non-normative masculinities (particularly homosexuality) sends a clear message to men that they will only be seen as 'true' men if they reject both femininity and subordinate masculinities. The hegemonic model of masculinity, then, is fragile, its boundaries vulnerable and in need of protection from a variety of Others. Under hegemonic masculinity, manhood can only be affirmed by renouncing all that is feminine, leading Kimmel to characterise both historical and contemporary manhood as “defined more by what one is not rather that who one is" (Kimmel 1994: 126- italics added).

The above definitions of masculinity rely on Gramci's concept of hegemony in order to understand manhood. Some scholars have begun to question the hegemony paradigm in masculinity studies, arguing that rather than focusing on ascertaining whether men attempt to embody or reject local versions of hegemonic masculinity, it can be fruitful to move beyond the hegemonic/subordinate masculinity dualism. Inhorn/Wentzell, for example, prefer to emphasise the "emergent masculinities" that they have observed among men in Mexico and the Middle East as a result of their interaction with reproductive and sexual health technologies (Inhorn/Wentzell 2011: 802). Inhorn/Wentzell argue that the term emergent masculinities can capture incipient forms of masculinity that in many cases are a reaction against harmful forms of hegemonic masculinity dominant locally (Inhorn\&Wenzell 2011: 803). I agree with their emphasis on constant change and dynamism in manhood the world over (the phenomenon they note of some Mexican men proclaiming themselves to be "ex-machistas" is particularly promising). However, the internal male hierarchy posited by hegemonic masculinity continues to offer a sound theoretical framework for understanding manhood amongst men whose masculinity is also informed by race, caste and class relations. While emergent forms of masculinity question some aspects of local gender regimes, no doubt many other characteristics of these regimes are left unchallenged, such as the cultural taboo on homosexuality. 
Furthermore, in the case of the Spanish Ravidasssias, their preeminent community institution for gender training, the temple, has thus far not served as a space for efforts to create gender anew in the face of migration (although there are moves in this direction in other locations such as Canada), but rather has served to reinforce gender conformity.

The visions of masculinity advanced by Connell, Kimmel, and Goffman are also rooted in Western culture. This leaves many regional hegemonic versions of masculinity, relatively unexplored, although there is now a growing body of literature dedicated to the study of South Asian masculinities. The colonial legacy in the Punjab, in which Sikhs (the majority religion of the Punjab), were classified as a "martial race” by the British and heavily recruited into the Imperial army, continues to be felt today in pride in Punjabi military prowess, contributing to an image of Punjabis as courageous fighters. The Sikh faith ${ }^{3}$ (founded in 1469 by Guru Nanak, a social reformer), has also influenced Punjabi manhood. Although Guru Nanak stressed the equality of all human beings and was particularly progressive with regards to women's rights, his teachings have always been overshadowed by a patriarchal culture. The Sikh gender scholar Nikky Singh, argues that the creation of the Khalsa Sikh identity by the tenth Sikh Guru in 1699, led to the development of a "hypermasculine" Sikh identity based on a male-centered initiation ritual and five masculine symbols of religious identity, the most emblematic of which is the turban (Kaur Singh: 1995). In their article on Sikh masculinity, Chanda and Ford argue that the turban has become the key marker of the "religio-cultural masculinity" of Sikh men (Chanda \& Ford 2010: 462). Analysing the collection of short stories penned by the female Sikh author Shauna Singh Baldwin, they state that the common trope throughout can be identified as the turban as the "sine qua non of Sikh manhood" (Chanda \& Ford 2010: 463).

In addition to religion, caste is central to the performance of hegemonic Punjabi masculinity. Two studies carried out in the Punjab focused on Jat men (the most powerful caste group in 
Punjabi society) stress the importance of owning and cultivating land in forming a hegemonic Jat-based masculinity. Chopra, in her study of masculinity in a Punjabi village, found that a Jat's manliness is measured by how he ploughs his land and carries himself with pride, leading them to disparage landowners from other castes for lacking the same supreme manliness (Chopra 2004: 44). Thus manual work is exalted and is seen to create a specifically Jat habitus that is hyper-masculine and unique to the Jats only. In a similar vein, Gill in his study of the representation of masculinity in Punjabi cinema, describes how the heroes in Punjabi films are consistently Jat landowners, whose masculinity is marked by their caste identity and embodied through traditional agricultural dress and the ability to cultivate land (Gill 2012: 113). Apart from their relationship to the land, Gill argues that the masculinity of Punjabi film heroes is furthermore demonstrated by their ability to move effortlessly between the space of the village and town, and also transnationally, via migration (Gill 2012: 109). If land ownership and cultivation is central to the self-worth of upper-caste Jat men, how do low-caste men cultivate manliness? Jackson points out that low-caste men who are manual labourers frequently experience frustration and feelings of failure with regards to their expected role as provider (Jackson 2007: 102). A study among the low-caste Vanniyars in Tamil Nadu carried out by de Neve, has revealed that although many men in this community struggle to attain economic comfort, a growing minority has managed to achieve upward mobility, espousing what he calls "patron" and "householder" models of masculinity that imitate the masculinities of higher ranking caste groups (de Neve 2004: 72-81).

The Ravidassias, have a very different relationship to the land from the Jats, as they were traditionally the manual labourers who were hired by Jat landowners to carry out menial agricultural tasks. For much of Punjab’s history they have thus been excluded from hegemonic masculinity, marked by poverty and economic dependence. Their relationship to the turban is 
also more ambiguous. Although a universal Sikh symbol, it has particularly been important in the construction of Jat Sikh masculinity, and in the linking of Jatness=Sikhness. Lower caste Sikhs, on the other hand, no matter how orthodox, often must prove their 'Sikhness', and by implication, their manliness. Lower caste Sikhs are less likely to wear the turban and in some cases have actively rejected it. They occupy a marginal space in relation to hegemonic Punjabi masculinity, much in the same way as Cantú's sample of gay Mexican men are marked as “outside the imagined 'Mexican' community” (Cantú 2009: 33). The strategy of the Ravidassias to recover their masculinity has been to invest in caste pride, along with upward economic mobility. When a Ravidassia man states: "we are just as well settled as the Jats", he is simultaneously affirming "we are just as manly as them”. We can therefore observe a pattern of a group of subaltern men reclaiming their honour and masculinity being repeated: under British colonialism Indian men sought to defend themselves from negative colonial representations through reclaiming control over Indian women (Sinha 2010: 223). The key difference is that Ravidassia men are investing in hegemonic masculinity's role of man as provider in order to restore community pride.

While Ravidassia women are also called upon to uphold traditional gender roles, it is Ravidassia men who are expected to prove the community's economic strength to the upper castes. Nowhere is this task as pressing as in the diaspora, where inter-caste economic competition is intense, and the Ravidassias have been freed of their structurally subordinate relationship to the Jats. Although casteism in the Spanish diaspora remains rife, there is little caste-based difference in employment status. Both Jats and the Ravidassia are employed in the construction/catering industries and struggle to attain legal status. The traditional casted economic hierarchy that predominates in the Punjab thus no longer applies in the Spanish 
context, where Ravidassias are able to assert economic and hence masculine muscle on a par with their upper caste peers.

The situation of the Ravidassias demonstrates that a group of men that are positioned as subordinate in relation to the masculinity of upper-caste Punjabi men can nonetheless invest psychologically in that same model of hegemonic masculinity in order to prove both individual and collective self-worth. Indian hegemonic masculinity then, rather than simply marginalising low-caste men, can simultaneously serve as a strategic resource in their quest for social recognition and equality.

\section{Methodology}

The fieldwork for this paper was carried out over a period of two years (2009-2011) and employed an anthropological methodology of ongoing participation observation in the Ravidassia temple and in family homes, as well as carrying out repeat, in-depth, semistructured interviews with young Ravidassia men (in the 18-30 age group). The background of my interviewees varied but certain commonalities existed: ideologically, the majority of my interviewees had strong Ravidassia identities and several were Ambedkar followers (Ambedkar was the founder of modern India's Dalit rights movement), making them more conscious about Dalit human rights. Of those who were still studying, all were enrolled in vocational training programmes that do not prepare one for university. My older interviewees (aged 24 and above) were unemployed, but unofficially worked at various odd jobs in the underground economy, except for two interviewees who worked in the construction industry. They all come from the Doaba region of the Punjab, which is noted for its high migration rates and migration 'mania' among its youth. All interviewees except for two were from the " 1.5 " generation of men who migrated with their families to Spain as schoolchildren or early 
adolescents. Only one interviewee had a university degree (one of the first generation men). Interviews were conducted mostly in Spanish at a local university, and not in the temple, where there was no privacy. 1.5 generation men are fluent in Spanish, it is the language they employ with their friends, and increasingly amongst themselves. Initial contact with interviewees was made through the temple, as well as the "snowball" method, resulting in a core sample of fifteen young men. As a female anthropologist, trust with my interviewees was established through my identification as a caste ally, through extended time spent with a variety of families within the community, and through having previously interviewed the same sample about their caste and religious identities.

\section{The Temple as Gendered Space and Institution}

In order to understand how the masculinities of men in the diaspora are shaped, it is important to discuss a key site for gender training: the Ravidassia temple. While formally a caste-specific space in which Ravidassias can freely practice their heterodox religious identity, the temple is also impregnated with gender norms that shape and limit the behaviour of women and men. The heart of the temple is the holy book, which sits under a throne and is reverentially bowed to before sitting on the floor. Just as public sex-differentiated toilets create rather than reflectgendered differences in the West (Goffman 1977: 316), so too are the institutional practices of the temple effective in producing naturalised gender differences. The gendered nature of the temple and its multiple gendered boundaries is evident from the moment one enters its confines. As is the norm for temples in the diaspora, men and women sit separately. These gender boundaries are fixed for adults- only small children are free to come and go between the male and female sections during religious services. Such tolerance ends once children reach adolescence and are expected to begin performing culturally mandated gendered 
scripts. Gendered segregation continues after religious services, during the vegetarian meal that is served, and in the socialising that follows, with men and women chatting amongst themselves and keeping to their respective gendered spaces. The gendered nature of the temple is further reinforced by the different clothing that men and women wear: all adult women wear traditional Punjabi dress whereas men wear Western dress, and tie a handkerchief to cover their heads. Within the temple, women are thus bound to enact a specifically Punjabi femininity.

The temple as gendered institution is reflected in the male monopoly of all roles of authority and prestige. Amongst the Barcelona Ravidassias, women are present as passive observers only. Men sing religious hymns, lead prayers, prepare/serve food ${ }^{4}$, and transport the holy book, all tasks known as seva or community service, which is usually temple-based, but also includes service to the wider community. The priest is male, as is also the case in temples worldwide. All leadership positions on the temple management committee are occupied by men. Although carrying out seva is voluntary, it greatly enhances one's social standing within the community.

Each gender adheres to a highly ritualised form of behaviour and body language that is considered appropriate to a religious place of worship, as well as to ideals of masculinity and femininity. The temple is therefore a setting in which what Goffman terms "genderisms", which he defines as "sex-class" specific behavioural practices (Goffman 1977: 305), are ritually performed- a sacred repetition which confirms the naturalness, the biological 'essence' of gender differences. It is also a space in which young Ravidassias learn to police their enactment of masculinity/femininity, in what Foucault terms a "regime of practice" (1978) and Martino calls a "regime of self-surveillance" (Martino 2000: 215). Young women who 'voluntarily' choose not to carry out seva and young men/women who studiously ignore each other's presence, are abiding by gendered regimes of self-surveillance, which over time, become second nature. 
The social moulding forces at work in the temple do not imply that its gendered scripts are completely successful, but rather that within the temple, children learn that a certain type of gendered script must be enacted in order to be seen as 'proper' boys and girls, and also 'good' Punjabis. Outside of the temple, youth have greater freedom to perform masculinity/femininity differently. Within the temple, however, there is very little room for flexibility- boys must conform to a hegemonic Punjabi masculinity and girls to a hegemonic Punjabi femininity ${ }^{5}$. The temple, in conjunction with other socialisation agents, thus produces culturally specific versions of masculinity/femininity that boys and girls must perform if they are to be socially accepted. The temple is successful in enforcing normative gender standards because these standards are at the same time conflated with being Punjabi. The successful performance of hegemonic masculinity and femininity within the temple and at home is seen as maintaining Punjabi culture- for both genders. Indeed, in the diaspora, gender norms assume new significance because they also serve to distinguish Punjabis from Spaniards- cultural boundaries are simultaneously gendered. An example from my participant observation in Punjabi family homes can serve to illustrate how Punjabi culture in the diaspora is strongly linked to a certain conception of gender roles. One Punjabi husband, in response to his wife's assertion that she would have remained vegetarian in Spain even if her husband had insisted she eat meat, was jokingly reprimanded by her husband warning her: “don't you become Spanish!” (i.e. too 'modern'). Although his tone was not threatening, his message was clear. Another man, married with three children, shared that he was glad that Punjabi women continued to adhere to higher standards of modesty than their Spanish counterparts. The same dynamic operates in the temple, with boys and girls encouraged to enact a Punjabi identity that is tied to conservative definitions of masculinity and femininity. 


\section{YOUNG PUNJABI MASCULINITIES}

\section{Gender Roles and Awareness of Inequality}

Most of the young men that I interviewed had never reflected before on their masculinity, or on gender issues in general. Well-versed in speaking about caste, several were perplexed with my questions about gender. I interviewed both 1.5 young men, as well as two first generation young men who had been living in Spain for more than a year. With the notable exception of one young man possessing egalitarian views on gender relations, the vast majority of these youth adhered to conservative gender ideologies in which gender inequalities were naturalised, and awareness of gender bias was limited. These results parallel the findings of the recent “International Men and Gender Equality” survey of gender attitudes among men from six different countries, including India. ${ }^{6}$ This survey found that Indian men were consistently the least 'gender equal' amongst all men surveyed, and the most antagonistic towards gender equality. For example, 81 percent of Indian men affirmed that "men should have the final word about decisions in home” (compared to 24 percent in Mexico) and 86 percent felt that childcare was a woman's responsibility (compared to 61 percent in Rwanda and 10 percent in Brazil). A further 65 percent believed that "there are times when a woman deserves to be beaten”, which contrasts starkly with the next highest percentage of 21 percent in Rwanda (Evolving Men 2011: 19). While my results certainly do not reveal the same extremes of patriarchal thinking, a general mindset prevails in which gender inequalities are not questioned, or even 'seen'. Thus most interviewees, in response to my question regarding gender differences in the temple, affirmed that there was "no difference" between girls and boys in the temple- that all were "treated the same”. One man admitted that women don't speak in the temple "due to shame”, but the most extensive comments came from the one and only gender egalitarian interviewee, 
who observed that women were more conservative, and linked this conservativeness to cultural restrictions rather than some innate shyness in females:

"Boys are more activist. They participate more than girls, are involved in more activities. Girls are more conservative, because according to our culture, a girl who is active will be badly seen. A girl who is seated quietly there is a good girl” (Balminder, male, 21 years, Barcelona)

The male monopoly on leadership roles within the temple is taken for granted and not seen as exclusionary. Women are implicitly assumed to not be interested in or suitable for temple management positions. While not openly opposed to greater participation on the part of women (one interviewee claimed that "ladies are welcome to get involved"), neither was their total absence seen as problematic. The status quo was accepted and not seen as an example of systemic inequality, but rather just the 'way things are at the temple'.

Young men similarly affirmed that girls and boys were treated the same at home in response to my question on whether they felt brothers and sisters were subject to different treatment/expectations at home. The overwhelming response was, as with the state of gender relations in the temple, "the same". The sex-specific roles assigned to their sisters is seen to be part of the natural order of things, and the greater mobility restrictions placed on them are not questioned or viewed as discriminatory, but rather seen as protecting women. "We have more freedom” agreed a 1.5 young man, but felt that the comparative lack of freedom suffered by young women was justified, since "it is not as safe for girls to go roaming about”. Only the gender egalitarian man remarked that boys and girls inherit, rather than 'naturally' adopt, the gendered tasks carried out by their parents, and asserted that boys are more valued and spoiled at home. 
Their views on the respective roles of husband and wife reveal that the traditional gendered division of labor remains the dominant model, even among 1.5 youth exposed to the new Spanish norm of both partners working outside of the home. One eighteen year old began by stating that both husband and wife should have equal rights. He continued however with a conservative discourse on gender roles within marriage:

"She can work, but I will also give her the option to stay at home. I prefer that she stay at home, it will be better for both the marriage and the children. Until the children are fourteen or fifteen, the woman should stay at home” (Kulwinder, male, 18 years, Barcelona).

His comments reveal that the decision on whether his wife works outside the home is seen to be his prerogative. The husband's primary role continues to be identified as that of breadwinner for the family. Thus 18 year old Kulwinder says that the principal duty of a husband is to provide for his family, and that of the wife to respect her husband, and if she does not work, to carry out the household tasks. 22 year old Mohinder went one step further and asserted that while he wants his wife to pursue her own interests, he does not want her to work, "because that would be against my manhood”. 25 year old Sandeep stressed duty and complementarity in the roles of husband and wife, using the metaphor of a train to describe marriage:

"A train needs two wheels. One wheel is the wife, the other is the husband. The husband is supporting the wife. Wife is also supporting the husband. She prepares food for the husband, in-laws, children. She cleans the home. It is duty. If you don't do it, how is married life possible? Otherwise you will need a servant, but wife is part of home. Without a wife one cannot make a home” (Sandeep, male, 25 years, Barcelona). 
The above quotes reveal that there is no difference in the ideological adherence to Indian dominant masculinity between first generation migrants and "1.5" men who migrated as children. Although no explicit reference was made to the Jats in their comments, their responses must be situated in the broader socio-economic context of Punjabi society, in which in contrast to Jat women, many Ravidassia women were traditionally forced to work outside of the home. This has led to a perceived 'masculine deficit' that Ravidassia men are keen to overcome. In stressing their roles as providers, they are also stating that they intend to 'make it' economically in the diaspora on a par with other caste groups. These comments also reflect the general socioeconomic profile of Punjabi migration to Spain and continental Europe more broadly, which is largely low-skilled and with low levels of education (typically not more than a secondary school education). This contrasts with the highly skilled/highly educated profile of the Punjabi community in the US, where female labor force participation is much higher. There are incipient signs however that some 1.5 generation young unmarried women in Spain are beginning to change this trend.

\section{WHAT MAKES A MAN?}

\section{Economics}

What emerges clearly as the touchstone of Punjabi masculinity is the ability to provide economically for one's family and the drive to achieve wealth. All men agreed that without the ability to earn, one was lacking in masculinity. A man might not be well-built or handsome (characteristics that are valued on the Punjabi marriage market), but if he succeeds in being a breadwinner, he will have preserved his manhood and hence his izzat, or honour. This result 
partially coincides with the research conducted on white and East Asian boys in a Canadian secondary school by Athena Wang. Wang discovered that the Asian boys in her study identified dominant masculinity in Asian cultures with family and financial responsibility- although many of the boys did not agree with this model and rejected its inequality (Wang 2000: 117). In contrast, in my sample, Punjabi youth personally identified with this breadwinning version of masculinity and fully expected to live up to its ideals. 27 year old Sunil elaborated upon the importance of money to manhood in the following way:

"Izzat is directly proportional to money and the job you have. It is something put into the mind of every Indian boy by his parents. They need to have decent jobs, earn money. First is money, second is dressing properly, behaviour comes third, sports being the least important” .

All the men that I spoke with stressed their economic goals and their desire to be "well-settled". Indeed, the decision to migrate from the Punjab is driven by this desire to be economically successful, and then flaunt this wealth back home. They have seen other NRI's (Non Resident Indians) ostentatiously display wealth on their trips back to their native villages, and they too lust after the elevated social status that such consumerism brings. For first generation men who have migrated to Spain independently, often irregularly, the desire to succeed is particularly strong, since they have invested and risked a great deal in order to reach Europe. Men who have migrated irregularly have paid up to 25000 Euros to "agents" in order to pursue their migration dreams in the West and have the added pressure of recouping that family investment by sending money home. Nobil Ahmad, in his discussion of illegal male migrants from Pakistan, shows that for many men, the romantic appeal of illegal migration as a status symbol in itself is an important factor driving the migration industry despite the high cost (Nobil Ahmad 2008: 137). The exercise of illegal migration is thus a masculinity-affirming project, 
confirming the bravery and adventure-seeking of those who make it, but in order to complete the dream, it must be married to economic success in their eventual country of destination.

Men are also well aware that without a stable economic base, they will not be able to compete on the marriage market. Indeed, it is the prerequisite for marrying. The more he earns, or the greater his future earning potential, the higher the dowry his family can command. Current dowry rates for the highest earning and most prestigious occupations now reach as much as 500000 Euros. Men who are not able to fulfill the breadwinning ideal feel emasculated- one interviewee related to me the atypical case of a recently arrived Punjabi man who was initially supported economically by his wife while he learned Spanish and adjusted to life in Spain. The man in question was described as feeling "humiliated", and "less of a man” until he found a job. A number of men emphasised that not only was economic power important, but also the ability to be one's own boss. "I don't want to spend all of my life working for someone else” was how 21 year Balminder put it.

The responsibility of men in upholding Ravidassia identity through the adoption of hegemonic masculinity, is made clear in their repeated comments highlighting how the Ravidassia community "has come up" economically, provoking jealousy on the part of the upper castes, particularly the Jats, their main competitors in both the Punjab and abroad. One man, whose father owns a construction company, proudly informed me that his father also employs Jats, in a dramatic reversal of the traditional economic relationship between the two groups. Others stressed how the Ravidassias were now "catching up" with and even surpassing the Jats, in both education and employment, in a narrative that continually highlighted their growing collective strength, and their rising ability to compete on an equal level with Jats.

\section{Physical and moral strength}


A second key theme in Punjabi mardangi, or manhood in both Hindi and Punjabi, is physical strength. This aspect of masculinity appears to be universally valued. Wang in her study found that both Asian and white secondary school boys concurred that a man's physical build and strength were important and the foundation of male power in society (Wang 2000: 117). Martino, in his study of masculinity among boys attending a Catholic high school in Australia, found that "demonstrating physical strength, being able to attract the opposite sex readily and engaging actively in sports” were necessary in order to achieve a high status masculinity (Martino 2000: 226). The International Men and Gender Equality survey reports that Indian men in particular attach great importance to physical strength: a resounding 86 percent agreed that "to be a man, you need to be tough" and 92 percent agreed with the statement "if someone insults me, I will defend my reputation with force if I have to” (Evolving Men 2011: 19). In the Punjab, crafting strong bodies via hard physical labour on the land has been particularly important in a young Jat man's transition to full manhood (Chopra 2004: 47).

For Ravidassia men living in the diaspora, physical strength continues to retain its importance. One man, in response to my question about what image he associates with mardangi, raised his fist in a show of strength. Masculinity is seen as synonymous with physical strength on the part of all the men in my sample. Men should be big, strong, and above all courageous. In fact, this moral strength is equally important, and a vital part of what constitutes an aslimard, or ideal man (most often translated as ‘real man’ by my interviewees). This crucially distinguishes men from women, who instead of "becoming strong”, “just wear make-up” according to 18 year old Ashok. For 22 year old Mohinder, masculinity is characterised above all by the ability to be fearless and is linked to one's role as noble protector of one's family, womenfolk, and society in general: 
"Masculinity for me is to have the capacity to die. Not to fear death. It is very important for masculinity- it is basic. You must know how to die for an aim, for others....You must know how to protect your family, your women. If not, I lose my beghera (honour). When I go out with my mother, I am her protector. Bring food to your family, don't depend on anyone else. If my mother has to ask for money from someone else, we lose our honour...Also to be a mard(a man) is to protect everyone, not just your family. To be responsible for the whole society, and help the weak...”

20 year old Alwinder echoed the importance of social responsibility in defining mardangi, but stressed that this must include respect for women:

“An aslimard (ideal man) is someone who is courageous, ready to take responsibility, compassionate, helpful, who knows how to respect women, elders. He understands his role, is ready to face challenges. He is the opposite of a namard (not a real man) who does not have these qualities, does not know how to respect women and who is also impotent”.

23 year old Malwinder emphasized that honesty/integrity is a further key aspect of mardangi:

“A real man is true to his word. He is a responsible person, he does his duty very well. He is an honest man. He fulfills his word. He is fully prepared for others and fully involved in the social field. It is difficult to find such men today. I am not $100 \%$ aslimard because I have some money problems”.

Thus for many Punjabi men, physical strength and social responsibility go hand in hand. Being physically strong is important, but equally, if not more important, in their conceptualization of masculinity are qualities such as courage, honesty, and the ability to take responsibility for others, primarily one's family, but also to assume a leadership role in their community as a 
whole. Physical and moral strength are also linked in Ravidassia narratives to defending the entire Ravidassia community from upper caste aggression. A number of my interviewees related to me an incident of violence perpetrated by three upper-caste men against a Ravidassia man (before the 2009 split from Sikhism) at the entrance to the Ravidassia temple, in which he was beaten and the Ravidassia community was accused of disrespecting the tenets of the Sikh faith due to their non-orthodox worship practices. ${ }^{7}$ Central to their accounts was how other community members quickly came to his aid, and how community leaders subsequently denounced the aggression to the police. Ravidassia men were keen to point out how they not only managed to repel their upper-caste aggressors, but also subsequently defended their religious practices to other temples, thus excercising moral strength and leadership in challenging the allegations of religious impropriety leveled against them. The social responsibility aspect of mardangi thus assumes vital importance for Ravidassia men who feel the need to defend their community and the legitimacy of their religious practices.

\section{Heterosexuality}

The third theme to emerge in Punjabi masculinity is so taken for granted, that it was never explicitly named. An unspoken assumption running throughout my interviews was the belief that a 'true' man is heterosexual, the sine qua non of manhood. The importance of heterosexuality to Punjabi masculinity was reflected indirectly in the recurring theme of marriage and in the emphasis on family life in general. The centrality of family is common to all Indian migrants, where it serves to define Indian identity abroad. In her study of highly skilled Indian IT workers in the US, Varrel found that family "was an obsessive topic" among her interviewees; critical to Indian identity reproduction (Varrel 2011: 339). In Punjabi culture, a proper man is someone who complies with his social and religious duty to marry a woman 
and procreate. A man who does not marry is a social failure, and furthermore morally suspect. Since marriage is equated with responsibility and "being settled", it also symbolises one's entry into adulthood. Verma and Sharma, in their study of masculinity among low-income men in India, found that a crucial social attribute of mardangi was the ability to produce children, along with possessing physical attributes that would help them attract women (Verma\& Sharma 2004: 73).

To not marry, or to enter into a non-heterosexual partnership, is therefore unthinkable- equal to a form of social death. With marriage, comes enhanced respect and social status. While marriage is not the only life goal of men as it is for women, men are similarly taught that marriage is an obligatory rite of passage; one that along with fatherhood, confers full manhood. Most young men, when asked about their future plans, took for granted that they would get married and have children. Marriage was seen as a vital part of one's journey through life. One interviewee succinctly expressed this by stating that "according to an Indian, life is incomplete if you don't marry”. A common thread in my interviews was the difference between Spanish and Punjabi masculinities in this regard. Spanish men were seen to be unconcerned with marriage/family life, in contrast with Punjabi men who had clearly defined life plans to follow. Thus the message I saw painted on a number of buses in the Punjab of "no wife, no life", could be the motto of many Punjabi men. Indeed, Sandeep, with his love of popular sayings, told me his life philosophy could be summed up in the following way: "no life without wife". The 'sacred heterosexuality' ideology of diasporic Punjabi men thus plays a foundational, although not explicitly acknowledged role in their masculinity.

If heterosexuality is implicitly discussed when mentioning marriage, homosexuality is invisible. Given the importance of heterosexuality to proving manhood, its polar opposite of homosexuality must be avoided at all costs in order to maintain the boundaries of hegemonic 
masculinity. As Connell states, for many men homosexuality is a negation of masculinity, which leads to masculinity being defined by its hostility towards gay men and hegemonic masculinity being founded on the twin pillars of heterosexuality and homophobia (Connell 1992: 736). This extends to everyday conversation, where even mentioning the term homosexual is taboo. Homosexuality in India is universally rejected among all religious groups and castes. While homosexuality is also devalued in Spanish culture, and was severely punished during the fascist Franco regime, Spanish society has in recent years initiated a more open discussion of homosexuality and passed an equal marriage law in 2006.

The following example reveals the cross-cultural nature of hegemonic masculinities, and how each culture can evolve different ways of censoring homosexual desire. Such is the stigma attached to homosexuality that the practice of holding hands between men ceases upon settling in Spain, due to its Western connotation of homosexuality ${ }^{8}$. Thus a common feature of Indian masculinity is quickly suppressed in a new context with a different brand of hegemonic masculinity. My interviews reveal that the Western taboo on overt physical contact between men becomes incorporated into the new Punjabi masculinity in Spain. 25 year Sandeep described how soon after arriving in Spain, he quickly learned the new 'rules of the game':

"In Punjab, there is an open culture. No problem. In college I held hands all the time. But when we are here, we walk separately. When I was new, I went to hold my friend's hand and he said no, don't hold my hand. The Spanish boys will say you are maricón” (a derogatory term in Spanish for gay men).

18 year old Ashok, although he came to Spain as a pre-adolescent with his family, also rapidly learned that all physical contact with boys was henceforth off-limits: 
"In my country we walk hand in hand- we are friends only. But here no, they (the Spanish) think it is something else"

Given the increased visibility of homosexuality in Spanish society, there is also greater pressure to 'advertise' one's heterosexuality compared to the Punjab, where homosexuality is invisible. Thus Ashok similarly learned that by employing anti-gay insults and jokes, he could bolster his own masculinity within the masculine regime in Spain, where to be gay is to occupy the lowest rung on the ladder of masculine hierarchy- akin to the status of ex-untouchables within the caste system in India. Ashok related how at work, anti-gay 'banter' is the norm:

“At work, my boss will say, are you maricón? as a joke. Do you want to go to a gay bar? Just for laughs. We say “what's up maricón”. Boys learn to insult early”.

In stark contrast to the 'sacred heterosexuality' ideology and practice that permeates the temple and Punjabi culture in general, one interviewee broke the silence that shields this topic by speaking frankly about his own personal experience of a same-sex encounter:

“There was this young Pakistani guy who worked near my place, next to the supermarket. I often saw him giving me smiles, and then finally one day he engaged me in conversation. A conversation with the usual questions, my story, his story, but the truth was he was actually interested in having sex...Well we ended up having sex and me changing my supermarket cause I didn't want see him again. All these guys sleep with men but it just ends there, cause at the end of the day, they all hope to and want to get married. Even this guy, right after having sex asked me when I was going to get married! For these guys, doing anything sexual with another guy doesn't mean anything. It's something they do but you don't talk about it the next day, you just pretend 
it never happened. And these very men are married and have kids today, and the chapter is closed forever” (Rabat, 27 years, male, Barcelona)

As the above quote suggests, regardless of same-sex behaviour, individual desires are subordinated to collective norms. Fully aware that heterosexual marriage is the only path that is socially sanctioned in Punjabi society, anything that deviates from the norm is forgotten and buried- further feeding the collective silence that rules on this topic. In fact, homosexuality is often quietly tolerated as long as such information does not become public and appearances are maintained. What most creates scandal is not the existence of homosexuality in itself, but its social visibility. One of my interviewees, for example, acknowledged that some Punjabi men (allegedly Pakistani) engaged in prostitution with Spanish men. Although he clearly disapproved of this, he tolerated its existence due to financial necessity, but would never accept an openly gay couple attending temple. This pragmatic tolerance of homosexuality as long as it does not interfere with one's duty to bear children, provide for one's family and contribute to the extended family's honour more generally, is echoed by Badruddin Khan's study of homosexual activity in Pakistan. Khan asserts that it is less risky for married men to engage in same-sex extra-marital affairs than opposite sex ones, as long as they are discreet (Khan 1997: 277). It is clear that Punjabi masculinity, as with many other masculinities across the globe, rests both implicitly and explicitly on the pillar of heterosexuality. To be a man in Punjabi culture is to be a heterosexually married family man. Homosexuality is thus symbolically exiled from the Ravidassia community (reflected in statements such as "there are no gays in the temple”), viewed as alien and displaced onto other masculinities. As long as homosexuality remains private and hidden, it is tolerated, but public masculinity performance must be firmly heterosexual. 


\section{Dalit Masculinities: The Dual Challenge of Caste and Ethnicity in the Diaspora}

Although the discrimination that ethnic minority men face in the West might lead one to conclude that their masculinity might be negatively affected by the process of immigration and the subsequent stigmatisation of their ethnic identities, my interviews reveal the exact opposite result. Although no doubt many men hid the extent to which they felt their manhood had suffered in Spain, Punjabis possess a great deal of pride in their culture, which has helped to cushion the blow of lowered social status in Spain. The process of immigration and 'cultural juggling', in which men must juggle both Spanish and Indian culture, has led to a reinforcement of traditional gender ideologies. The continued caste prejudice that the Ravidassia face in the diaspora has also led to an incipient 'Ravidassia pride' movement in which young men are the key protagonists. While all men were unanimous in valuing their masculinity on a par with that of their Jat peers, an underlying theme consisted of the need to prove their manhood to the upper castes.

The performances of casted and classed masculinity in India and Spain vary, influenced by both space and the broader culture. In his study of lower-middle class male youth in Meerut, Uttar Pradesh, Jeffrey concluded that young men of the Jat, Dalit and Muslim castes formed temporary and at times fragile bonds of male solidarity in carrying out "time pass" in local tea shops, excluding both the urban poor and all women from these all-male spaces (Jeffrey 2010: 476). In rural Punjab, Chopra found that colonising the street functioned as a vital space for young men to develop a more egalitarian masculinity with male friends in contrast to the hierarchical masculine relations that they encountered at home and in the fields (Chopra: 2004). In Spain, young Punjabi men do not use their occupation of tea shops or the street in order to build male solidarity and perform masculinity (ies). Nor is soccer a focal point for affirming masculinity and ethnicity, as is the case among young South Asian men in the UK (Westwood 
1995: 214). I found that Dalit men used both caste pride, participation in caste associations, and the exaltation of Indian gender norms as a way to bond and assert their masculinity. The recent proliferation of "Chamar Pride" songs that have emerged over the last few years in response to the much longer tradition of "Jat Pride” songs, serve to re-assert the manhood of Dalit men. Young men would discuss the latest songs in the temple and share their favourite videos on social networking sites. Several young Ravidassias spoke of the positive effect of these songs on their self-esteem, termed a "collective awakening" by one of my interviewees. By reclaiming pride in their caste identity, they are simultaneously re-asserting their masculinity and self-respect. This finding partially coincides with the research carried out among young South Asian men in the UK by GautamMalkani. Malkani found that South Asian men used their ethnic identities as "props" to bolster their masculinities (Malkani: 2006). In particular, he highlighted how ethnicity was employed strategically in the abusive term "coconuts", to refer to South Asian men who are brown on the outside, white on the inside; in their homophobic banter, this term was linked with being effeminate or gay (Malkani: 2006). While the term “coconut”, or a parallel term, did not emerge during my fieldwork, what did emerge was the importance of caste identity, as opposed to a broader ethnic identity, in asserting masculinity. The focus on ethnicity and religion in much of the migration and integration literature has thus obscured how other vectors of identity, such as caste, can be just as important. Punjabi men from the Ravidassia caste 'advertise' their masculinity to their male upper-caste peers, who are an important cultural reference point for Dalit men. Nowhere is this more evident than in the example of one of my interviewees, who during the course of my fieldwork, defiantly attached a sticker to his bicycle proclaiming "Putt Charmaran de" (Son of Chamars) , imitating the much longer Jat tradition of glorifying their patrilineal heritage, in song and film (Putt Jattan de or Son of Jats). Caste pride and self-respect were also cultivated through participation in caste associations, and in particular, a new Ambedkarite association 
that gives young men a leadership role and voice in the community. Given that Dalit men are often excluded from both dominant caste associations and ethnic Catalan associations, the Ambedkarite association is a place where they can develop their leadership skills outside of the realm of the elder-controlled temple. This trend of forming masculinity-affirming ethnic associations was also observed among immigrant men in 1920’s America (Sinke 2006: 299).

The second way in which Punjabi men have asserted their masculinity is through assigning a superior value to the Indian gender regime, and hence to Indian culture. The expectation that they might start to question some aspects of their gender regime in response to contact with the Spanish gender regime has not been born out. Scholars of Moroccan immigrants in France (Andezian, Streiff, Guerraoui) have also found that immigration does not lead Moroccan men to change their ideas about traditional gender roles (Dialmy 2010: 18). Punjabi men repeatedly and universally affirmed that their masculinity was superior to that of Spanish men. While it may be argued that many men consider their masculinity to be superior to that of other groups, I did not find this to be the case in informal discussions with Spanish men. The ranking of masculinities is therefore far more important for men who are positioned as minorities.

A study conducted among male Lebanese secondary school students in Sydney by Poynting, Noble \&Tabar found that as a response to the 'silent injuries' of racism, Lebanese immigrant male youth ranked the masculinity of Anglo Australian boys below both that of their own as well as that of (East/South-East) Asian boys, due to their lack of ability to fight, and their weak internal solidarity (Poynting, Noble\&Tabar 1999: 71). The lack of respect accorded to their own group, reflected in derogatory terms such as “wog”, was repaid in turn by withholding respect for the “Aussies” (Poynting, Noble \&Tabar 1999: 72). Although my interviewees did not face the humiliation of being called "Paki”, a similar dynamic of ranked masculinities came 
into play whereby the dominant ethnic group was symbolically dethroned via a devaluation of their masculinity.

Thus, although Punjabi men could be considered to have a marginalised masculinity on account of their perception as low-status, new immigrants, most Punjabi men are firmly wedded ideologically to Indian hegemonic masculinity, and use this gender ideology to assert their value as a community. When asked 'who is more manly'?, they did not hesitate to declare themselves more masculine due to their role as breadwinners, pointing out that Spanish women work, hence depriving Spanish men of this vital aspect of masculinity. The words of 18-yearold Kulwinder are representative:

"Punjabis are more manly than the Spanish. In our culture the woman doesn't do anything, the man does everything, like a locomotive, he directs and all the others follow him. When you provide for your wife and children you are more manly. Here women work”.

Despite their struggles to find work and establish themselves, they are confident in the knowledge that in providing for their families, they are fulfilling one of the most important 'commandments' of manhood. A critical step for a young Punjabi man in "becoming settled" is also to purchase his own home, which is often a prerequisite for marriage. One of the men I interviewed had already (with the help of an uncle) purchased an apartment at the young age of 21. Home ownership is thus one of the steps along the path to full manhood. Far from feeling inadequate, Punjabi men expressed pride in their gender code, which stresses duty and family responsibility, which they contrasted with the "unmarried life" common in Spain. Although Punjabi and Spanish men share a number of key features of masculinity, such as the importance of heterosexuality and economic status, what emerges quite clearly is that the masculinity of Punjabi men is more collective in character, more subject to community demands. The masculine individualism of Spanish men is generally frowned upon. 
Young Dalit men living in the Spanish diaspora thus perform their masculinities in the context of two contrasting dominant masculinities: Jat masculinity, which has historically devalued their community and Spanish masculinity, which lumps the Ravidassias in the all-embracing and low-status category of immigrant. In responding to both models, young Dalit men are crafting masculinities that use the breadwinning model of hegemonic masculinity to assert masculine and community pride.

\section{Conclusion}

The vast majority of Dalit Punjabi men identify psychologically with Indian hegemonic masculinity, through which they are proving the collective strength of their community against a history of poverty. Providing for their families, being able to demonstrate physical and moral strength and following heterosexual codes of marriage were identified as the most important aspects of Punjabi manhood. Living in Spain and coming into contact with another gender regime has had a limited impact on the performance of their masculinitity, with the notable exception of Punjabi men ceasing to hold hands given its stigmatising consequences. Punjabi men do not feel that their masculinity has been marginalised. On the contrary, they consider themselves to be manlier than the Spanish, and do not aspire to imitate the Spanish model of masculinity (identified with “enjoyment”, but also a lack of responsibility and married family life). Their hierarchy of masculinities ranks the masculinity of men of the dominant ethnic group very low on the scale, precisely in response to their lack of real ethnic power in Spain. However, in adhering to Indian hegemonic masculinity, they do aspire to imitate the masculinities of the upper castes, which are intimately linked to economic status. This study of diasporic Punjabi masculinity reveals that it is not just Punjabi women, but also Punjabi men who bear a collective symbolic burden in defending gendered community boundaries and 
affirming group identity. The key difference is that this symbolic burden is manifested through family authority and economic mobility, rather than through dress and other bodily indicators as with women. Thus the response to becoming a minority ethnic group in a foreign land is critically gendered, and men have been playing an important role in defending their community via the performance of dominant Punjabi masculinity. Caste similarly plays a critical role in shaping masculinities; in the case of the Ravidassias, asserting caste pride is central to reclaiming lost masculinity. In the context of South Asian masculinities, rising Dalit assertion will therefore change the configuration of masculine hierarchies in Punjabi society. When assessing the influence of migration on masculinity, it is important to consider how the rite of passage that migration represents can significantly enhance the 'masculine capital' of Dalit men; living in Europe enhances their social prestige back home, which provides a boost to masculinity despite sacrifice and risk. However, in order for this newly acquired masculine capital to bear dividends, it must be married to upward mobility that vindicates the worth of the Ravidassia community as a whole in relation to other caste groups. What emerges is a genderscape in which Dalit Punjabi men perform Indian hegemonic masculinity both to compete among themselves, prove to the upper castes that they are equally manly, and distinguish their culture from the Spanish. 


\begin{abstract}
${ }^{1}$ First generation refers to the first wave of migration to a country.
${ }^{2}$ The term Dalit refers to all former untouchables in India. It is considered a 'bottom-up' term originating from Dalit activists in contrast to Ghandi's 'top-down' term of "Harijan".
\end{abstract}

${ }^{3}$ Sikhism is an independent religion that has been influenced by both Hinduism and Sufi Islam. There are approximately 25 million Sikhs worldwide, the vast majority of whom live in the Punjab state of India.

${ }^{4}$ In many gurudwaras in Canada, the US and the UK women play an active role in food preparation. However, in Barcelona, this was not common practice. In the Ravidassiagurudwara this was in part due to the fact that several young men, recent arrivals from the Punjab, lived in the gurudwara, cooked their meals there daily, and also prepared langar (holy meal) on Sundays.

${ }^{5}$ Although Connell speaks of an "emphasised femininity" and does not employ the term hegemonic femininity, I maintain that the term hegemony can be applied equally to both masculinities and femininities. Women are equally subject to a hierarchy of femininities in which one particular mode of femininity is valued above all others, which subordinates and marginalises all other forms of femininity

${ }^{6}$ The six countries in question are: India, Brazil, Chile, Rwanda, Croatia and Mexico. The Indian sample consisted of 1, 534 men between the ages of 15-59 interviewed in Delhi and Vijayawada (in Tamil Nadu).

${ }^{7}$ The Ravidassia community in Spain, as well as globally, follows a number of worship practices that deviate from the Sikh norm. In addition to referring to Ravidass as guru rather than saint (for orthodox Sikhs only the 10 officially recognized Gurus can hold that title), Ravidassias are accused of allowing visiting babas or spiritual leaders to sit at the same level of the Sikh holy book, which is forbidden by the Sikh RehatMaryada or code of practice. The ritual prayer that concludes collective worship, known as ardas, also differs in a Ravidassiagurudwara, In particular, the collective chant sung at the very end of the religious service exalts Guru Ravidass.

${ }^{8}$ A process that according to an Indian-resident interviewee is also occurring in urban India due to the influence of Western media

This research received no specific grant from any funding agency in the public, commercial, or not-for-profit sectors.

\title{
REFERENCES
}

Ahmad, A.N. 2008. The romantic appeal of illegal migration: Gender, masculinity and human smuggling from Pakistan. In Illegal Migration and Gender in a Global and Historical Perspective, edited by M. Schrover, J. Van der Leun, L. Lucassen \& C. Quispel. Amsterdam: Amsterdam University Press, pp. 127-150. 
Chanda, G.S., and Staci, F. 2010. Sikh Masculinity, Religion and Diaspora in Shauna Singh Baldwin’s English Lessons and Other Stories.Men and Masculinities 12 (4): 462-482.

Cantú, L. 2009. The Sexuality of Migration: Border Crossings and Mexican Immigrant Men. New York: New York University Press.

Chopra, R. 2004. Encountering masculinity: an ethnographer's dilemma. In South Asian Masculinities: content of change, sites of continuity, edited by R. Chopra, C. Osella, F. Osella. Delhi: Kali for Women, pp. 36-59.

Connell, R. W. 1995. Masculinities. Berkeley: University of California Press.

Connell, R.W.1987. Gender and Power: Society, the Person, and Sexual Politics. Stanford: Stanford University Press.

Connell, R.W. 2005. Globalization, Imperialism and Masculinities.In $\underline{\text { Handbook of Studies on }}$ Men and Masculinities, edited by M. S. Kimmel, J. Hearn and R.W. Connell. Thousand Oaks: Sage Publications, pp. 71-89.

Connell, R.W. 1992. A Very Straight Gay: Masculinity, Homosexual Experience and the Dynamics of Gender. American Sociological Review 57 (6): 735-751.

De Neve, Geert. 2004. The workplace and the neighbourhood: locating masculinities in the south Indian textile industry. In South Asian Masculinities: content of change, sites of continuity, edited by R. Chopra, C. Osella, F. Osella. Delhi: Kali for Women, pp. 60-95. 
Dialmy, A. 2010. Which Sex Education for Young Muslims? Paper presented at The World Congress of Muslim Philanthropists, Doha.

Evolving Men: Initial Results from the International Men and Gender Equality Survey.International Center for Research on Women and InstitutoPromundo. 2011.

http://www.promundo.org.br/en/wp-content/uploads/2011/01/Evolving-Men-IMAGES-1.pdf (Accessed 11 March 2011).

Gill, H. 2012. Masculinity, mobility and transformation in Punjabi cinema: From Putt Jattan De (Sons of Jat Farmers) to Munde UK De (Boys of UK). South Asian Popular Culture 10 (2): 109-122.

Goffman, E. 1977.The Arrangement between the Sexes.Theory and Society 4 (3): 301-331.

Hoodfar, H. 1997. The Veil in Their Minds and on Our Heads: The Persistence of Colonial Images of Muslim Women. In Politics of Culture in the Shadow of Capital, edited by D. Lloyd and L. Lowe. Durham: Duke University Press.

Inhorn, M.C and Wentzell, E.A. 2011.Embodying emergent masculinities: Men engaging with reproductive and sexual health technologies in the Middle East and Mexico. American Ethnologist 38 (4): 801-815.

Jackson, C. 2007. Men's Work, masculinities and gender divisions of labour. The Journal of Development Studies 36 (1): 89-108. 
Jeffrey, C. 2010. Timepass: Youth, class, and time among unemployed young men in India. American Ethnologist 37 (3): 465-481.

Khan, B. 1997.Not-So-Gay Life in Pakistan in the 1980’s. In Islamic Homosexualities: Culture, History and Literature, edited by S. Murray and W. Roscoe. New York: New York University Press, pp. 93-104.

Kimmel, M. 1994. Masculinity as Homophobia: Fear, Shame and Silence in the Construction of Gender Identity. In Theorizing Masculinities, edited by H. Brod and M. Kaufman. Thousand Oaks: Sage Publications, pp. 119-141.

Kimmel, Michael, 2000. The Gendered Society. Oxford: Oxford University Press.

Malkani, Gautam. 2006. "What's right with Asian boys". FT.com. http://www.ft.com/cms/s/0/9f2bb9fc-d03b-11da-b160-0000779e2340.html\#axzz1jv2WbJTN (Accessed 10 May 2006).

Martino, W. 2000.Policing Masculinities: Investigating the Role of Homophobia and Heteronormativity in the Lives of Adolescent School Boys.The Journal of Men's Studies 8 (2): 213-236.

Poynting, S, Noble, G and Tabar, P. 1999. 'Intersections' of Masculinity and Ethnicity: a study of male Lebanese immigrant youth in western Sydney. Race, Ethnicity and Education 2 (1): 59-77. 
Rao, S. 1999. Woman-as-symbol: The intersections of identity politics, gender and Indian nationalism. Women's Studies International Forum 22 (3): 317-328.

Ray, S. 2000. En-Gendering India: Women and Nation in Colonial and Postcolonial Narratives. Durham: Duke University Press.

Singh, N. Kaur. 1995. The birth of the Khalsa: A feminist re-memory of Sikh identity. Albany: State University of New York Press.

Sinha, M. 2010. Gender and Nation. In Feminist Theory Reader: Local and Global Perspectives, edited by C. McCann and S. Kim. New York: Routledge, pp. 212-231.

Sinke, S. 2006. Gender and Immigration. In A Companion to American Immigration, edited by Reed Ueda. Oxford: Blackwell, pp. 289-308.

Varrel, A. 2011. Gender and intergenerational issues in the circulation of highly skilled migrants: The case of Indian IT professionals. In Gender, Generations and the Family in International Migration, edited by A. Kraler, E. Kofman, M. Kohli\& C. Schmoll. Amsterdam: Amsterdam University Press, pp. 335-353.

Verma, R \& Sharma, M. 2004. Construction of Masculinity in India: A gender and sexual health perspective. Journal of Family Welfare 50: 71-78.

Wang, A. 2000. Asian and White Boys' Competing Discourses About Masculinity: Implications for Secondary Education. Canadian Journal of Education 25 (2): 113-125. 
Westwood, S. 1995. Gendering Diaspora: Space, Politics, and South Asian Masculinities in Britain. In Nation and Migration: The Politics of Space in the South Asian Diaspora, edited by P. van der Veer. Philadelphia: University of Pennsylvania Press, pp. 197-221. 